\title{
Increased Binding of Epidermal Growth Factor to Placental Membranes of Intrauterine Growth Restricted Fetal Rats
}

\author{
STEWART LAWRENCE, WENDY STENZEL, AND JOSEPH B. WARSHAW \\ Departments of Pediatrics University of Texas, Southwestern Medical School, Dallas, Texas, and Yale University \\ School of Medicine, New Haven, Connecticut 06510
}

\begin{abstract}
To examine the relationship between nutrient supply and fetal and placental growth, we examined epidermal growth factor (EGF) binding to membranes prepared from placentas of growthrestricted fetal rats. Intrauterine growth retardation was accomplished by unilateral ligation of the uterine artery; fetal rats on the contralateral uterine horn served as controls. Fetal growth restriction was accompanied by decreased placental wt at 19 and 20 days' gestation and significantly decreased placental glycogen content at 20 and 21 days, $30 \%$ and $15 \%$, respectively. Placental DNA content and protein/DNA ratios were similar in the growthrestricted and control groups. Specific binding of ${ }^{125}$ I-EGF was increased in growth-restricted placentas at 19 and 20 days' gestation by $32 \%$ and $16 \%$, respectively. ${ }^{125}$ I-EGF binding at 20 21 days increased linearly with the extent of placental growth restriction. Competitive binding experiments yielded linear Scatchard plots with an increased receptor density in growth-restricted placenta at 19 and 20 days' gestation, $74 \%$ and $60 \%$, respectively. Binding affinities for the EGF receptor were similar in the two groups. The increased binding of EGF to membranes prepared from growth-restricted fetal rats may serve to enhance nutrient uptake under conditions of decreased uterine blood flow. (Pediatr Res 25: 214-218, 1989)
\end{abstract}

\section{Abbreviations \\ EGF, epidermal growth factor \\ TGF $\alpha$, transforming growth factor \\ IUGR, intrauterine growth retarded}

Fetal growth and maturation is determined primarily by the fetal genome but can be influenced by a number of important genetic, environmental, and maternal factors. These include a variety of congenital malformations and chromosomal disorders, environmental toxins such as cigarette smoke and alcohol, and maternal medical conditions which can restrict nutrient supply to the fetus. Fetuses with decreased uteroplacental blood flow may exhibit to varying degrees, depending on the severity of substrate and oxygen restrictions, low birth wt with sparing of brain growth, polycythemia, hypoglycemia secondary to defective glucose homeostasis, and accelerated lung maturation. The biologic mechanisms underlying the alterations in growth seen with decreased nutrient supply are poorly understood. In previous work (1-4), we reported that placentomegaly and maturational delay in fetuses of diabetics was associated with a striking decrease in the binding of epidermal growth factor to membranes prepared from the diabetic placentas. In light of these observations and because of the role of EGF in cellular proliferation and

Received May 23, 1988; accepted October 24, 1988.

Correspondence Joseph B. Warshaw, Department of Pediatrics, Yale Medical School, 333 Cedar Street, New Haven, CT 06510.

Supported by NIH Grant HL30119-07. organ differentiation in numerous cell types and animal species (5-7), we examined EGF binding to membranes prepared from placentas of fetal rats with growth restriction secondary to uterine artery ligation. In these studies, we raise the possibility that EGF binding to placental membranes is regulated by substrate flux and is associated with maturational changes in diabetic and IUGR fetuses.

\section{MATERIALS AND METHODS}

Animal model. Pregnant adult female Sprague-Dawley rats were obtained from Holtzmann Lab Animals (Madison, WI) at 7-9 days' gestation (the morning that sperm were detected was designated as day 0 of pregnancy). Females were maintained on a $12 / 12 \mathrm{~h} \mathrm{light} / \mathrm{dark}$ cycle at $24^{\circ} \mathrm{C}$, and given food and tap water ad libitum for 7-9 days before animal surgery. On days 16, 17, or 18 of gestation, unilateral uterine artery ligation was performed by a modification of the method of Wigglesworth (8) under Metofane (Pitman-Moore, Washington Crossing, NJ) inhalation anesthesia as follows. A midline incision of the lower abdomen was made, and the uterine horns were exteriorized and inspected. A single 3.0 silk ligature was placed securely around the main branch of the uterine artery close to the cervix. Only horns containing six or more fetuses were used for operation; the contralateral horn in each animal served as a control. The uterine horns were then replaced within the abdominal cavity; the peritoneum was closed with continuous sutures and the skin with wound clips.

Animals were killed by decapitation 3 days after surgery at 19 , 20 , or 21 days' gestation. Surviving fetuses and placentas from both uterine horns were weighed and immediately placed on ice for further dissection and analysis. Animal studies were carried out after appropriate institutional review.

Preparation of crude cell membrane fraction. Placentas were removed and weighed immediately after animals were killed. The membrane fraction was prepared by a modification of the method of Morishige et al. $(4,9)$. Tissue was homogenized in a polytron homogenizer in $10 \mathrm{vol}$ of $0.3 \mathrm{M}$ sucrose in $25 \mathrm{mM}$ Tris$\mathrm{HCl}, \mathrm{pH} 7.6$, containing $10 \mathrm{mM} \mathrm{MgCl}$. The resulting homogenate was centrifuged at $800 \times g$ for $10 \mathrm{~min}$, and the supernatant was then centrifuged at $20,000 \times g$ for $20 \mathrm{~min}$. The pellet was washed with $20 \mathrm{vol}$ of $25 \mathrm{mM}$ Tris- $\mathrm{HCl}$, pH 7.6, containing 10 $\mathrm{mM} \mathrm{MgCl} 2$ and underwent centrifugation at $20,000 \times g$ for 10 min. This wash was repeated twice. The final pellet was resuspended in $25 \mathrm{mM}$ Tris- $\mathrm{HCl}$, pH 7.6, $10 \mathrm{mM} \mathrm{MgCl}_{2}, 0.5 \%$ BSA at a dilution to yield approximately $3 \mathrm{mg}$ protein $/ \mathrm{ml}$. All procedures were performed on ice or at $4^{\circ} \mathrm{C}$. This fraction was then used in the binding experiments.

${ }^{125} I-E G F$ binding. Binding assays were carried out in a total vol of $0.25 \mathrm{ml}$ in $1.5 \mathrm{ml}$ polypropylene tubes. Each tube contained $300 \mu \mathrm{g}$ placental membrane protein, 30,000-40,000 dpm

${ }^{125} \mathrm{I}-\mathrm{EGF}(0.10-0.20 \mathrm{ng})$, sp act of $150-200 \mu \mathrm{Ci} / \mu \mathrm{g}$ (New England 
Nuclear, Boston, MA) and increasing amounts of unlabeled receptor grade EGF (Collaborative Research, Bedford, MA) in $25 \mathrm{mM}$ Tris- $\mathrm{HCl}$, pH 7.6, $10 \mathrm{mM} \mathrm{MgCl}_{2}, 0.5 \%$ BSA. The tubes were shaken continuously for $90 \mathrm{~min}$ at room temperature, at which point the reaction was terminated by the addition of 0.75 $\mathrm{ml} 50 \mathrm{mM}$ Tris- $\mathrm{HCl}, \mathrm{pH}$ 7.6. The tubes were centrifuged for 10 min at $10,000 \times g$ in a Beckman microcentrifuge (Beckman Instruments, Palo Alto, CA). The supernatant containing unbound EGF was removed and the pellet counted for $10 \mathrm{~min}$ in a Packard $5110 \gamma$-counter (Hewlett-Packard Co., Palo Alto, CA). Nonspecific binding was determined by the amount of ${ }^{125}$ I-EGF bound in the presence of $1000 \mathrm{ng}$ unlabeled EGF and was subtracted from all values to determine the amount of EGF specifically bound. EGF receptor number and affinity were determined by Scatchard analysis of the competitive binding assay data (10).

Degradation of ${ }^{125} I-E G F$. To assess possible differences in degradation of ${ }^{125} \mathrm{I}$-EGF tracer, specific binding was determined for membranes prepared from control and IUGR rat placentas and human placenta. The supernatant fractions remaining after the initial binding assays were each reincubated with human placental membranes, and specific binding was then compared to the initial binding for the human placental membranes.

Rebinding experiment. Magnesium chloride was used to dissociate EGF bound to receptor in the membrane preparations as described by Kelly et al. (11). Specific binding assays were performed as above for both membrane preparations. Immediately after counting, the pellets were resuspended in $0.5 \mathrm{ml}$ of 1 $\mathrm{M} \mathrm{MgCl}$ in binding assay buffer, vortexed, and incubated for 5 min. The reaction was terminated by the addition of $3.5 \mathrm{ml}$ of the binding assay buffer. The tubes were centrifuged at $2300 \times$ $g$ for $15 \mathrm{~min}$. After aspirating the supernatant, the pellet was counted and resuspended, and the binding assay was repeated.

Radioreceptor assay for $E G F$. The amount of EGF-like activity in amniotic fluid and fetal serum was measured by radioreceptor assay. Human placental membranes were isolated according to a modification of the method of Hock and Hollenberg $(4,12)$ and suspended at a concentration of $5-\mu \mathrm{g}$ membrane protein per tube. The assay mixture contained 30,000 to $40,000 \mathrm{dpm}{ }^{125} \mathrm{I}-$ EGF, varying amounts of cold receptor grade EGF (0-1000 ng/ tube), or test sample in a final vol of $300 \mu$ l. The binding mixture was incubated in Dulbecco's PBS, $250 \mathrm{mM}$ HEPES, $0.1 \%$ BSA, $\mathrm{pH}$ 7.6, at room temperature with continuous shaking for 60 $\mathrm{min}$. The reaction was terminated by the addition of $1 \mathrm{ml}$ of icecold incubation buffer and filtered through Whatman GF/C filters using the Millipore 3025 sampling manifold (Millipore Continental Water Systems, Bedford, MA) to separate bound from unbound ligand. The assay tube was washed once with 1 $\mathrm{ml}$ ice-cold buffer, and the filter was rinsed three additional times with ice-cold buffer. The filter was then counted in a Packard $5110 \gamma$-counter. A displacement curve of bound ${ }^{125}$ I-EGF versus $\log$ EGF concentration was constructed, and the EGF-like activity present in the test sample was estimated by the amount of ${ }^{125}$ I-EGF displaced.

Glycogen analysis. Samples of placentas and liver were weighed rapidly, flash frozen in liquid nitrogen, and stored at $-70^{\circ} \mathrm{C}$ until analysis. Glycogen content was measured as described previously (13).

Protein and DNA analysis. Total protein was measured by the method of Lowry et al. (14), using BSA as the standard. DNA was assayed by the method of Burton (15), using deoxyribose as the standard.

Statistical analysis. Student's $t$ test was used to compare results between control and growth-restricted groups. Data is expressed as mean $\pm \mathrm{SE}$.

\section{RESULTS}

Growth restriction. Unilateral uterine artery ligation resulted in variable survival on the ipsilateral uterine horn; a surviving fetus, for the purpose of these studies, was defined as having obvious spontaneous body movements within the amniotic sac and no evidence of resorption. The range of somatic growth restriction observed in individual fetal rats was from $0-40 \%$ less than the mean body wt of the fetuses on the contralateral uterine horn.

We confined our studies to those fetal rats with substantial growth restriction, defined for these studies as a $\geq 20 \%$ reduction in body wt as compared to controls from the contralateral horn. Body wt comparisons at 19,20, and 21 days' gestation are shown in Figure 1. The liver glycogen content was decreased by $39 \%$ in IUGR fetal rats, an observation consistent with previous studies using the Wigglesworth system of surgically induced IUGR (8).

Standardization of ${ }^{125} I-E G F$ binding assay. Figure 2 shows the binding of ${ }^{125} \mathrm{I}$-EGF as a function of increasing membrane protein. The specific binding was linear over the range of 100-700 $\mu \mathrm{g}$ protein. Total and specific binding of ${ }^{125} \mathrm{I}-\mathrm{EGF}$ also increased linearly from 30,000 to $300,000 \mathrm{dpm}$ of iodinated EGF.

Figure 3 shows the time course of binding to membranes prepared from placentas of control and IUGR rats. Specific binding was greater in the IUGR placental membranes than in controls over the entire 2 -h time course. The ratio of binding in

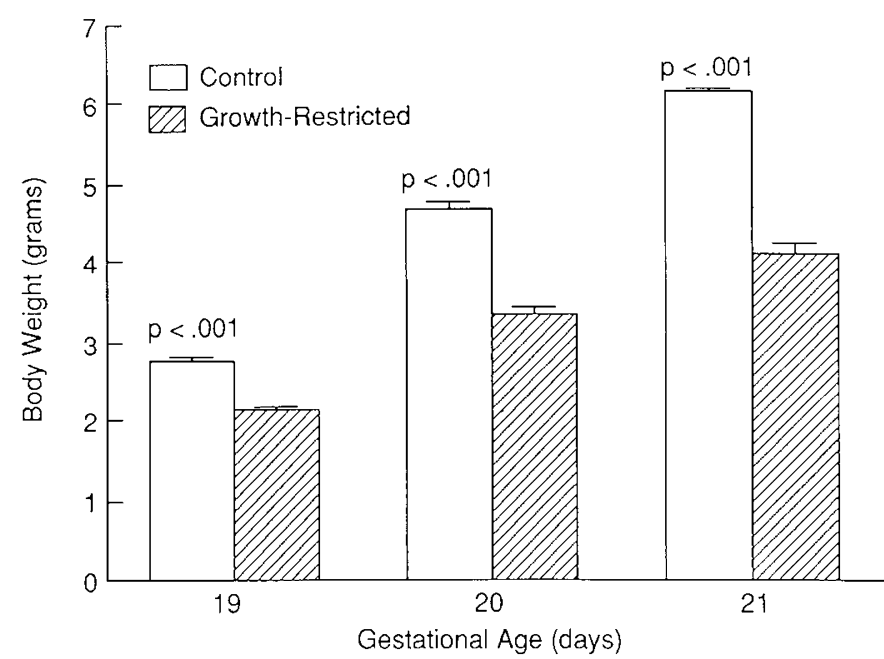

Fig. 1. Comparison of body wt of control and IUGR fetal rats at 19, 20 , and 21 days' gestation. Data represented as means \pm SE.

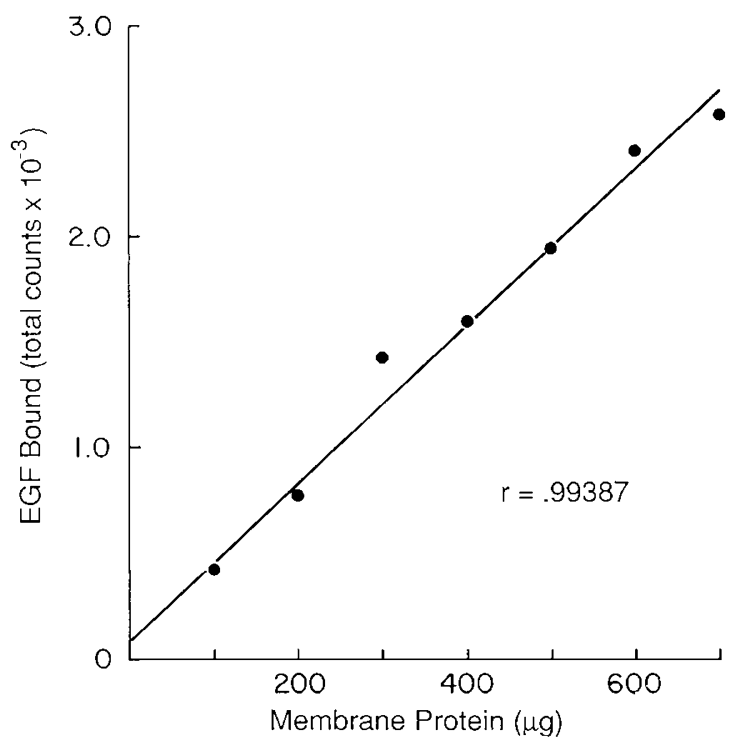

Fig. 2. Standardization of ${ }^{125} \mathrm{I}-\mathrm{EGF}$ binding to placental membrane: binding versus membrane protein. 
IUGR rats over controls remained consistent, making it unlikely that the increased binding of EGF to placental membranes from IUGR rats was due to different rates of EGF degradation.

Dissociation of the EGF-receptor complex. To determine whether or not the increase in ${ }^{125}$ I-EGF binding to membranes prepared from IUGR rats was due to a difference in occupancy of the receptor, $\mathrm{MgCl}_{2}$ was used to dissociate the ligand-receptor complex. Figure 4 shows the results of this experiment. Specific binding before dissociation and after rebinding reveals increases of 28 and $35 \%$, respectively, for placental membranes from IUGR rats. As the ratio of EGF bound before and after dissociation is approximately equal, it would appear that the receptors in both membrane preparations have the same degree of occupancy.

Placental biochemical studies. Placental wt, protein, DNA, and glycogen content at 19,20, and 21 days' gestation are shown in Table 1. IUGR placentas were decreased in size, as compared to control placentas, at 19,20 , and 21 days' gestation by $8 \%$, $14 \%$, and $13 \%$, respectively. These differences were statistically significant at 19 and 20 days. Placental growth restriction was less dramatic than fetal growth restriction, as demonstrated by the differences in fetal/placental ratios $(\mathrm{F} / \mathrm{P})$ with advancing gestational age (Fig. 5). The DNA concentrations in controls were not significantly different than those found in the IUGR placentas. Although the protein concentration at 21 days' gestation was slightly increased in IUGR placentas, the protein/DNA ratios were similar at the 3 gestational days which were studied. Placental glycogen content was significantly decreased in IUGR placentas at 20-21 days' gestation by $30 \%$ and $15 \%$, respectively.

Comparative binding of ${ }^{125} I-E G F$ in control and IUGR placenta. The specific binding in IUGR placentas at 19, 20, and 21 days is increased by $32 \%, 16 \%$, and $7 \%$, respectively, with the differences being statistically significant at 19 and 20 days' gestation. Specific binding versus placental growth (measured by wet wt) in IUGR fetuses at 20-21 days' gestation, as shown in Figure 6 , suggests a linear relationship between the extent of growth restriction in individual placentas and the binding of ${ }^{125} \mathrm{I}$ EGF. This relationship was not observed at 19 days' gestation.

Competitive binding experiments provided data that yielded linear Scatchard plots on days 19 and 20 of gestation in both control and IUGR placentas. Figure 7 shows a representative Scatchard plot of day 19 placenta membranes from control and IUGR rats. Linear regression analysis was used to estimate the receptor density and binding affinity $(\mathrm{Kd})$ of control and IUGR placentas for ${ }^{125}$ I-EGF on days 19 and 20 (Table 2). There was an apparent increase in receptor number in IUGR placental membranes on both days. Receptor density was increased in

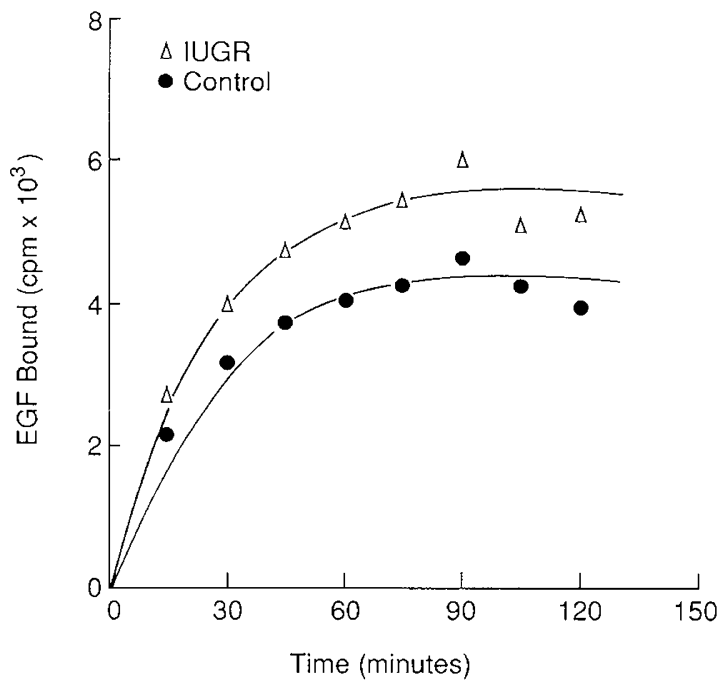

Fig. 3. Time course of ${ }^{125} \mathrm{I}-\mathrm{EGF}$ binding to placental membrane from control and IUGR rats: binding versus time of incubation.

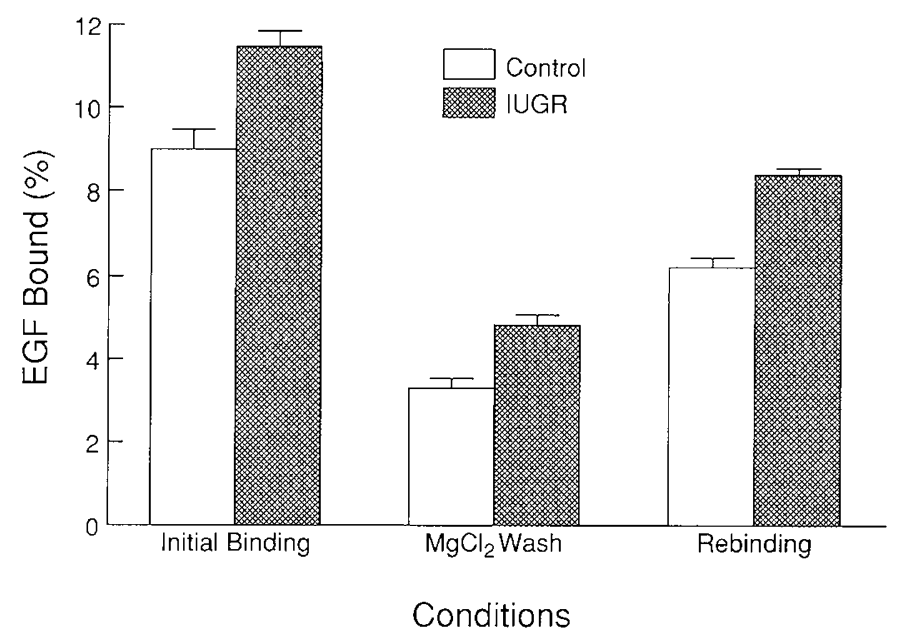

Fig. 4. $\mathrm{MgCl}_{2}$ removal of EGF bound to placental membranes from control and IUGR rats.

Table 1. Placental characteristics*

\begin{tabular}{|c|c|c|c|c|}
\hline & $\begin{array}{l}\text { Placental wt } \\
\text { (mg wet wt) }\end{array}$ & $\begin{array}{c}\text { DNA } \\
\text { (mg/g } \\
\text { wet wt) }\end{array}$ & $\begin{array}{c}\text { Protein } \\
(\mathrm{mg} / \mathrm{g} \\
\text { wet wt) }\end{array}$ & $\begin{array}{c}\text { Glycogen } \\
(\mu \mathrm{g} / \mathrm{mg} \\
\text { protein })\end{array}$ \\
\hline \multicolumn{5}{|c|}{ Day 19} \\
\hline Control & $\begin{array}{r}563 \pm 9 \\
(50)\end{array}$ & $\begin{array}{c}1.24 \pm 0.07 \\
(4)\end{array}$ & $\begin{array}{r}99 \pm 9 \\
(7)\end{array}$ & $\begin{array}{c}25.4 \pm 5.5 \\
(7)\end{array}$ \\
\hline IUGR & $\begin{array}{r}519 \pm 14 \\
(39)\end{array}$ & $\begin{array}{c}1.39 \pm 0.03 \\
\text { (4) }\end{array}$ & $\begin{array}{r}99 \pm 9 \\
(7)\end{array}$ & $\begin{array}{c}24.6 \pm 5.5 \\
(7)\end{array}$ \\
\hline \multicolumn{5}{|l|}{ Day 20} \\
\hline Control & $\begin{array}{r}622 \pm 14 \\
(49)\end{array}$ & $\begin{array}{c}1.27 \pm 0.12 \\
(8)\end{array}$ & $\begin{array}{r}105 \pm 5 \\
(18)\end{array}$ & $\begin{array}{c}14.3 \pm 1.0 \\
(12)\end{array}$ \\
\hline IUGR & $\begin{array}{r}535 \pm 16 \\
(42)\end{array}$ & $\begin{array}{c}1.21 \pm 0.12 \\
(8)\end{array}$ & $\begin{array}{r}108 \pm 3 \\
(16)\end{array}$ & $\begin{array}{c}10.0 \pm 0.5 \\
\text { (11) }\end{array}$ \\
\hline \multicolumn{5}{|l|}{ Day 21} \\
\hline Control & $\begin{array}{r}618 \pm 27 \\
(29)\end{array}$ & $\begin{array}{c}1.35 \pm 0.03 \\
(8)\end{array}$ & $\begin{array}{r}123 \pm 4 \\
(8)\end{array}$ & $13.0 \pm 0.5$ \\
\hline IUGR & $\begin{array}{r}540 \pm 34 \\
(30)\end{array}$ & $\begin{array}{c}1.43 \pm 0.02 \\
(8)\end{array}$ & $\begin{array}{r}134 \pm 4 \\
(8)\end{array}$ & $\begin{array}{c}11.1 \pm 0.3 \\
(8)\end{array}$ \\
\hline
\end{tabular}

* Values are \pm SEM with $n$ in parentheses.

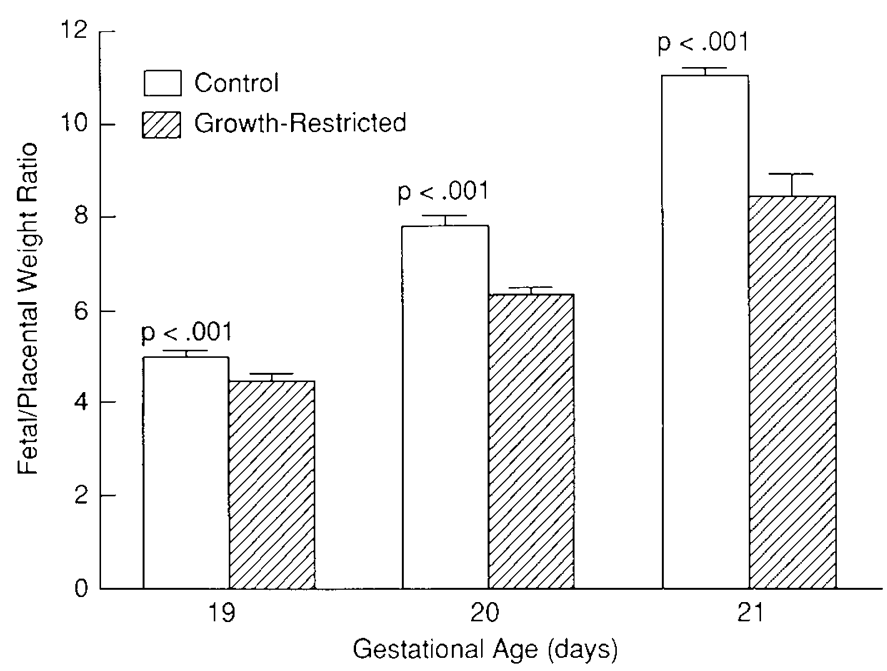

Fig. 5. Fetal/placental wt ratios of control and IUGR fetal rats at 19 , 20 , and 21 days' gestation. Data represented as means \pm SE.

IUGR placentas at 19 and 20 days by $74 \%$ and $60 \%$, respectively. The EGF receptors in control and IUGR placentas have similar binding affinities.

Degradation of ${ }^{125} I-E G F$. Supernatants from control and 
IUGR membrane preparations were each reincubated with human placental membranes. The specific binding was essentially equal. If the difference in binding seen in the membranes from control and IUGR rats were due to a higher rate of tracer degradation from the control membrane preparation, one would expect to see a similar decrease in binding in the supernatant fraction from the control tissue.

Radioreceptor assay. Results from radioreceptor assays for EGF-like activity are shown in Table 3. Levels of activity in fetal serum and amniotic fluid at 20 days' gestation were not significantly different between the control and IUGR groups.

\section{DISCUSSION}

We reported previously that membranes prepared from placentas of rats with streptozotocin-induced diabetes showed a striking decrease in the binding of EGF when compared with binding to control placental membranes (4). On days 21-22, this decrease in binding related primarily to the failure of a second class of lower-affinity receptors to appear in the diabetic placenta. We speculated that the excessive substrate supply to the diabetic fetuses resulted in sustained cell division and a concomitant delay in maturation of the diabetic placentas and that these alterations in placental growth and maturation may be modulated by the changes in EGF binding.

To examine further the relationships between substrate supply, EGF binding and placental maturation, we prepared placental membranes from fetal rats with growth restriction induced by uterine artery ligation (8). Fetuses were characteristically reduced

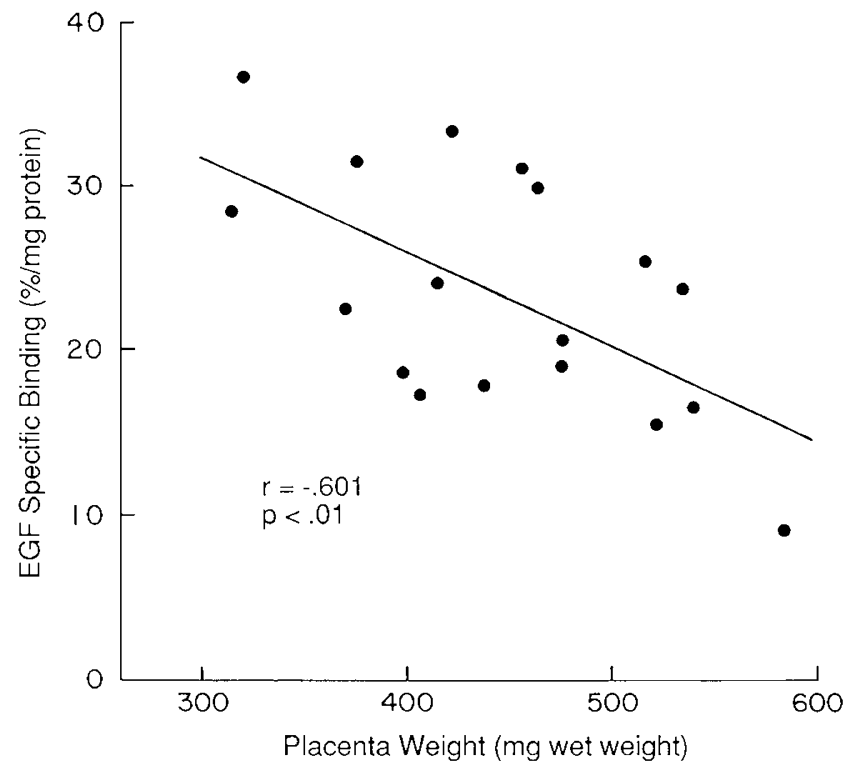

Fig. 6. Specific binding of ${ }^{125}$ I-EGF versus placental wt in IUGR placenta of 20-21 days' gestation. in wt by at least $20 \%$. Nitzan et al. (16) observed a large reduction in the placental transfer of glucose and amino acids to fetal rats with surgically induced growth restriction, but oxygen transfer is also likely diminished. The decreased availability of glucose in IUGR fetuses is associated with decreased accumulation of hepatic glycogen near the end of gestation, which we also observed.

The restriction of overall fetal growth was accompanied by decreased placental wt. Cell division within the rat placenta, as measured by DNA content, has essentially ceased by 16-17 days' gestation (1), which is before the time of uterine artery ligation. It is, therefore, not surprising that placental DNA concentrations of the IUGR fetuses were not significantly different from controls between 19 and 21 days' gestation. Placental growth during the last 5-6 days of the rat pregnancy represents hypertrophy, i.e. is associated with increases in cell protein and RNA, as shown by Winick and Noble (17). Placental protein in IUGR placentas in our studies was not significantly different than in controls at 19 and 20 days' and actually slightly increased at 21 days' gestation. Moreover, protein/DNA ratios were similar; therefore, the observed decrease in placental growth was unlikely to have been the result of protein malnutrition. Although the placental weights showed significant differences on days 19 and 20, the protein/ DNA ratios did not reach statistical significance on any of the days studied. Placental glycogen content, which has previously been shown to decrease in the rat pregnancy from 16 days onward (1), was further decreased in IUGR placentas at 20 and 21 days'

Table 2. Receptor density and binding affinity*

\begin{tabular}{clcc}
\hline Day & Group & $\begin{array}{c}\text { Receptor density } \\
(\mathrm{pmol} / \mathrm{mg} \text { protein })\end{array}$ & $\begin{array}{c}\text { Binding affinity } \\
(\mathrm{Kd})(\mathrm{nM})\end{array}$ \\
\hline \multirow{2}{*}{19} & Control & $85.1 \pm 6.0(n=5)$ & $0.49 \pm 0.05(n=5)$ \\
& IUGR & $148 \pm 28.3(n=4)$ & $0.58 \pm 0.07(n=4)$ \\
& & $p<0.05$ & $\mathrm{NS} \dagger$ \\
20 & Control & $104.9 \pm 13.2(n=4)$ & $0.62 \pm 0.08(n=4)$ \\
& IUGR & $168.4 \pm 9.6(n=4)$ & $0.59 \pm 0.03(n=4)$ \\
& & $p<0.01$ & $\mathrm{NS}$ \\
\hline
\end{tabular}

$* n$ represents the total number of binding experiments, each of which involved the measurement of competitive binding of ${ }^{125} \mathrm{I}-\mathrm{EGF}$ in membrane prepared from three to five placentas from the same pregnant animal.

$\dagger$ NS, not significant.

Table 3. Levels of EGF-like material in amniotic fluid and fetal serum*

\begin{tabular}{lcc}
\hline \multicolumn{1}{c}{ Group } & Serum $(\mathrm{ng} / \mathrm{ml})$ & Amniotic fluid $(\mathrm{ng} / \mathrm{ml})$ \\
\hline Control & $13.2 \pm 0.9(n=5)$ & $0.75 \pm 0.12(n=6)$ \\
Growth-Restricted & $12.0 \pm 0.6(n=4)$ & $0.69 \pm 0.14(n=4)$ \\
& NS $\dagger$ & NS
\end{tabular}

* Radioreceptor assay was carried out at 20 days' gestation as described in the text.

$\dagger \mathrm{NS}$, not significant.

\section{DAY 19}

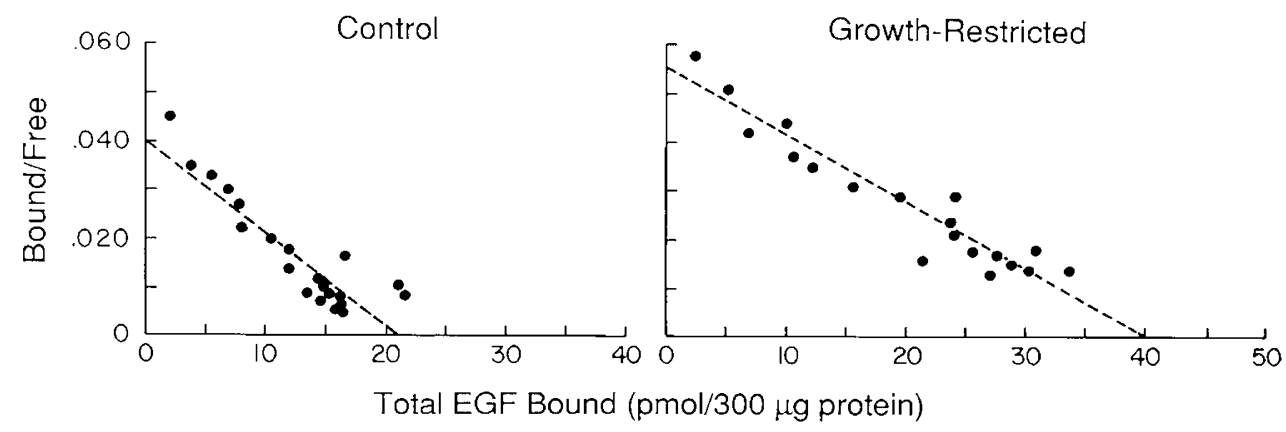

Fig. 7. Scatchard analysis of binding of ${ }^{125}$ I-EGF to placental membranes from control and IUGR fetal rats at day 19 of gestation. 
gestation. There may also have been quantitative differences in water content or other cellular constituents (e.g. cell membrane phospholipids) not measured in these studies that were responsible, in part, for the diminished tissue wt in IUGR placentas.

Diminished placental glycogen content has been observed in many species toward the end of normal gestation $(18,19)$ and is thought to occur secondary to the increased utilization of substrate for biosynthetic pathways by the fetal-placental unit (20). The decrease in glycogen content of IUGR placentas at 20-21 days' gestation may also be secondary to oxygen- and nutrientdeprivation.

The increased specific binding of EGF by IUGR placentas and the apparent relationship between the extent of placental growth restriction and EGF binding suggests that the EGF receptor may play a role in a nutrient-deprived environment. EGF stimulates the uptake of glucose, amino acids, and uridine (21-23) and is a mitogen $(24,25)$ in various in vitro systems. EGF receptor number increases toward the end of gestation in mice (26), rats (4), and humans (27), suggesting a relationship between maturation and EGF binding. The increased binding of EGF to membranes from IUGR fetuses may serve to enhance nutrient uptake under conditions of decreased uterine blood flow.

The changes in binding of EGF at days 19 and 20 of gestation in the IUGR rat placentas occurred secondary to an apparent increase in receptor number. The binding affinity of the receptor was not significantly different between IUGR and control placentas. EGF itself can cause synthesis of the EGF receptor, socalled up-regulation (28). Glucocorticosteroids can enhance EGF binding (29). Our studies have not, as yet, included the measurement of glucocorticosteroid levels or binding in control and IUGR fetal rats. Stress-associated increases in glucocorticosteroid levels in the IUGR fetus would not be surprising. The measurement of EGF-like activity as performed in the radioreceptor assay revealed no significant differences in levels between control and IUGR animals in either serum or amniotic fluid. Therefore, up-regulation by EGF would appear to be a less likely mechanism for the increased specific binding and apparent receptor density in IUGR placentas. It is important, however, to point out that the growth factor TGF $\alpha(30)$ has been demonstrated to bind with specificity to the EGF receptor, so measurements of EGF activity levels, as determined by radioreceptor assay, should be interpreted as EGF-like activity.

Finally, one could speculate that increased mRNA for the EGF receptor, or increased transcription of that message, results in an increase in synthesis of the receptor in IUGR placentas. EGF has been associated with increases in glucose and amino acid uptake in isolated cells. The greater receptor density as a response to nutrient deprivation suggests the possibility of an EGF-mediated increase in nutrient transport. Studies to quantify specific mRNA for the EGF receptor in control and IUGR placentas are currently in progress.

\section{REFERENCES}

1. Gewolb IH, Barrett C, Warshaw JB 1983 Placental growth and glycogen metabolism in streptozotocin diabetic rats. Pediatr Res 17:587-591

2. Gewolb IH, Meridian W, Warshaw JB, Enders AC 1986 Fine structural abnormalities of the placenta in diabetic rats. Diabetes 35:1254-1260

3. Gewolb IH, Rooney SA, Barrett C, Ingleson LD, Light D, Wilson DM, Walker Smith GJ, Gross I, Warshaw JB 1986 Delayed pulmonary maturation in the fetus of the streptozotocin-diabetic rat. Exp Lung Res 8:141-151

4. Sissom JF, Stenzel WK, Warshaw JB 1987 Decreased binding of epidermal growth factor in placentas from streptozotocin-diabetic rats. J Clin Invest $80: 242-247$

5. Sundell HW, Gray ME, Serenius FS, Escobedo MB, Stahlman MT 1980 Effects of epidermal growth factor on lung maturation in fetal lambs. Am J Pathol 100:P707-726

6. Catterton WZ, Escobedo MB, Sexson WR, Gray ME, Sundell HW, Stahlman MT 1979 Effect of epidermal growth factor on lung maturation in fetal rabbits. Pediatr Res 13:104-108

7. Carpenter G, Cohen S 1979 Epidermal growth factor. Annu Rev Biochem 48:193-216

8. Wigglesworth JS 1964 Experimental growth retardation in the fetal rat. J Pathol Bacteriol 88:1-13

9. Morishige WK, Uetake C, Greenwood FC, Akaka J 1977 Pulmonary insulin responsivity: in vivo effects of insulin on the diabetic rat lung and specific insulin binding to lung receptors in normal rats. Endocrinology 100:17101722

10. Scatchard G 1949 The attractions of proteins for small molecules and ions. Ann NY Acad Sci 51:660-672

11. Kelly PA, Leblanc G, Djiane G 1979 Estimation of the total prolactin binding sites after in vitro desaturation. Endocrinology 104:1631-1638

12. Hock RA, Hollenberg MD 1980 Characterization of the receptor for epidermal growth factor-urogastrone in human placenta membranes. J Biol Chem 255:10731-10736

13. Maniscalco WM, Wilson CM, Gross I, Gobran L, Rooney SA, Warshaw JB 1978 Development of glycogen and phospholipid metabolism in fetal and newborn rat lung. Biochim Biophys Acta 530:333-346

14. Lowry OH, Rosebrough NJ, Farr AL, Randall RJ 1951 Protein measurement with the Folin phenol reagent. J Biol Chem 193:265-275

15. Burton K 1956 A study of the conditions and mechanisms of the diphenylamine reaction for the colorimetric determinations of deoxyribonucleic acid. Biochem J 62:315-323

16. Nitzan M, Groffman H 1970 Metabolic changes in experimental intrauterine growth retardation. Isr J Med Sci 6:697-702

17. Winick M, Noble A 1966 Quantitative changes in ribonucleic acids and protein during normal growth of rat placenta. Nature 212:34-35

18. Corey EL 1955 Growth and glycogen content in the fetal liver and placenta. Am J Physiol 112:263

19. Villee CA 1956 Biochemical evidence of aging in the placenta. In: Wolstenholme GEW, Millar ECP (eds) CIBA Foundation Colloquia on Aging, vol 2. Churchill Co, London, pp 129-144

20. Gennser G, Lunquist I, Nilsson E 1972 Carbohydrate content and glycogenolytic activity in human placenta and fetal heart and lung. Biol Neonate 21:148-160

21. Barnes D, Colowick SP 1976 Stimulation of sugar uptake in cultured fibroblasts by epidermal growth factor and EGF-binding arginine esterase. J Cell Physiol 89:633-640

22. Cohen S, Taylor JM 1974 Epidermal growth factor: chemical and biological characterization. In: Greep RO (ed) Recent Progress in Hormone Research, vol 30. Academic Press, New York, pp 533-550

23. Covelli I, Mozzi R, Rossi R, Frati L 1972 The mechanism of action of the epidermal growth factor III. Stimulation of the uptake of labelled precursors into RNA, DNA and proteins induced by EGF in isolated tumor cells. Hormones 3:183-191

24. Carpenter G, Cohen, S 1976 Human epidermal growth factor and the proliferation of human fibroblasts. J Cell Physiol 88:227-237

25. Hoober JK, Cohen S 1967 Epidermal growth factor: II: increased activity of ribosomes from chick embryo epidermis for cell-free protein synthesis. Biochim Biophys Acta 138:357-368

26. Adamson ED, Meek J 1984 The ontogeny of epidermal growth factor receptors during mouse developments. Dev Biol 103:62-70

27. Carson SA, Chase R, Ulep E, Scommengna A, Benveniste R 1983 Ontogenesis and characteristics of epidermal growth factor receptors in human placenta. Am J Obstet Gynecol 147:932-939

28. Earp SH, Austin KA, Blaisdell J, Rubin RA, Nelson KG, Lee LW, Grisham JW 1986 Epidermal growth factor stimulates EGF receptor synthesis. J Biol Chem 261:4777 -4780

29. Baker JB, Barsh GS, Carney DH, Cunningham DD 1978 Dexamethasone modulates binding and action of epidermal growth factor in serum-free cell culture. Proc Natl Acad Sci USA 75:1882-1886

30. Anzano MA, Roberts AB, Meyers CA, Komoriya A, Lamb LC, Smith JM Sporn MB 1982 Synergistic interaction of two classes of transforming growth factors from murine sarcoma cells. Cancer Res 42:4776-4778 